\title{
ANALISIS FAKTOR-FAKTOR YANG BERKONTRIBUSI PADA TECHNICAL DELAY PESAWAT BOEING 777-300ER DI PT. GMF AEROASIA TBK
}

\author{
Puri Alodia Davirza*(1), Mufti Arifin(2), Freddy Fransiscus ${ }^{(3)}$ \\ (!)(2)(3)Prodi Teknik Penerbangan, Fakultas Teknologi Kedirgantaraan, Universitas \\ Dirgantara Marsekal Suryadarma \\ Komplek Bandara Halim Perdanakusuma, Jakarta 13610, Indonesia \\ *Corresponding Author: alodiapuri@gmail.com
}

\begin{abstract}
Abstrak - Maskapai Garuda Indonesia Airlines mengoperasikan sebanyak 144 pesawat untuk melayani rute domestik maupun rute internasional. Garuda Indonesia mempercayakan perbaikan dan perawatan pesawat (maintenance), serta technical handling kepada PT. GMF AeroAsia, Tbk. Pada operasional maskapai terdapat kemungkinan terjadinya technical delay yang mempengaruhi On Time Performance sebuah pesawat. Technical delay adalah keterlambatan penerbangan yang tidak sesuai dengan jadwal terjadi akibat penanganan teknik. Penelitian ini membahas faktor-faktor terjadinya technical delay yang mempengaruhi On Time Performance maskapai Garuda Indonesia Airline berdasarkan data selama satu tahun. Data technical delay selama tahun 2018 dikumpulkan dan dianalisis menggunakan metode Pareto. Hasil analisis menunjukkan technical delay disebabkan penanganan teknik yang tidak efektif dan efisien. Data yang didapatkan menunjukkan 19 kali $(52,78 \%)$ technical delay yang disebabkan oleh delay code 41,9 kali $(25 \%)$ disebabkan oleh delay code 43 , dan 8 kali $(22,22 \%)$ yang disebabkan oleh delay code 46 dari total 36 kali technical delay sepanjang tahun 2018. Analisis pareto ATA chapter menunjukkan ATA 28, ATA 27, dan ATA 52 mendominasi technical delay.
\end{abstract}

Kata Kunci: Technical Delay, On Time Performance, Boeing 777-300ER

\begin{abstract}
Garuda Indonesia Airlines operates 144 aircraft to serve domestic and international routes. Garuda Indonesia Airline entrusted aircraft repair and maintenance, as well as technical handling to PT. GMF AeroAsia, Tbk. In the operational of airlines there are possibility of technical delay that affects the On Time Performance of an aircraft. Technical delay is a flight delay that is not in accordance with the schedule due to technical handling. This research discuss the factors of technical delay that affect Garuda Indonesia Airline's On Time Performance based on one year data. Technical delay data in 2018 were collected and analyzed using Pareto method. The result of analysis found that technical delay due to ineffective and inefficient technique handling. The data shown 19 times (52.78\%) technical delay caused by delay code 41, 9 times (25\%) caused by delay code 43, and 8 times (22.22\%) caused by delay code 46 of the 36 times technical delay throughout year 2018. ATA Chapter Pareto Analysis shown that technical delay dominate by ATA 28, ATA 27, and ATA 52.
\end{abstract}

Keywords: Technical Delay, On Time Performance, Boeing 777-300ER,. 


\section{PENDAHULUAN}

Salah satu kebutuhan manusia pada saat ini adalah berpindah dari satu tempat ke tempat lain dalam jangka waktu yang cepat. Untuk dapat berpindah dalam jangka waktu yang cepat, membutuhkan alat transportasi yang berteknologi canggih dan mutakhir. Salah satu alat transportasi yang dapat memindahkan manusia dari satu tempat ke tempat lain secara cepat adalah moda transportasi udara. Baik itu adalah pesawat udara khusus penumpang, pesawat jet pribadi, maupun helikopter yang mampu melayani penerbangan jarak dekat dan mendarat dari gedung ke gedung lainnya.

Pesawat udara penumpang dimiliki oleh sebuah maskapai penerbangan. Maskapai penerbangan merupakan perusahaan yang menjual jasa transportasi menggunakan moda transportasi udara. Dalam melayani penumpang para maskapai saling bersaing untuk merebut pasar konsumen. Persaingan tidak dapat dihindarkan antara satu maskapai penerbangan dengan maskapai lainnya. Baik penerbangan domestik maupun internasional, semuanya sama-sama bersaing untuk memberikan kesan terbaik kepada para konsumennya. Salah satu maskapai yang ada di Indonesia adalah Garuda Indonesia Airlines. Garuda Indonesia Airlines merupakan perusahaan maskapai penerbangan BUMN (Badan Usaha Milik Negara).

Dalam persaingannya sebagai maskapai penerbangan yang melayani rute domestik di Indonesia dan rute internasional tentu Garuda Indonesia harus memperhatikan faktor-faktor yang dapat menyebabkan terjadinya delay pada suatu perusahaan maskapai penerbangan. Faktor-faktor tersebut seperti penanganan penumpang, operasional maskapai penerbangan, serta penanganan teknik dan ground handling. Semua faktor-faktor tersebut harus dipastikan tidak mengalami kendala yang berarti dalam penanganannya karena dapat memempengaruhi On Time Performance dari sebuah maskapai penerbangan. Garuda Indonesia sendiri sampai saat ini masih memiliki permasalahan dalam menangani kendalakendala dari faktor-faktor tersebut.

Kendala-kendala tersebut salah satunya disebabkan oleh kendala teknik seperti masalah yang terjadi pada pesawat, pergantian roda pesawat, dan apabila tidak bisa dilakukan pergantian suku cadang secara cepat maka terpaksa pesawat harus ditukar atau diganti dengan yang tersedia pada waktu itu. Apabila hal ini terjadi maka ditakutkan delay yang terjadi bisa saja tidak hanya dalam hitungan menit atau jam. 
Ada beberapa type pesawat yang digunakan oleh Garuda Indonesia pada saat ini diantaranya yaitu Boeing 777300ER sebanyak 10 unit, Boeing 737-800 sebanyak 81 unit, Boeing 737 Max 8 sebanyak 1 unit, Airbus 330-300 sebanyak 13 unit, Airbus 330-200 sebanyak 9 unit, ATR 72-600 sebanyak 11 unit, dan CRJ 1000 sebanyak 18 unit, untuk melayani rute domestik maupun rute internasional. Adapun jumlah ketersediaan armada juga mempunyai impak terhadap On Time Performance apabila mengalami delay teknik.

Dari latar belakang permasalahan di atas, dapat diketahui bahwa kegiatan penanganan teknik memiliki peranan penting untuk menghindari terjadinya delay sehingga perlu dilakukan. penelitian terhadap faktor-faktor Technical Delay terhadap On Time Performance pada Pesawat Boeing 777-300ER di PT. GMF AeroAsia, Tbk.

\section{METODE PENELITIAN}

Pada penelitian ini, dilakukan pengumpulan bahan atau data yang digunakan sebagai referensi sebelum dilakukannya analisis.

Dalam penelitian ini, data yang digunakan adalah data kuantitatif dari manifest movement report technical delay maskapai Garuda Indonesia Airlines dari bulan 1 Januari 2018 hingga 31 Desember
2018 di Bandara Internasional Soekarno Hatta.

Metode analisis data yang digunakan dalam penelitian ini adalah Metode Pareto. Analisis Pareto dibuat berdasarkan sebuah konsep yang dikenal dengan Pareto's Law. Hukum Pareto menyatakan bahwa sebuah grup selalu memiliki presentase terkecil (20\%) yang bernilai atau memiliki dampak terbesar (80\%). Adapun langkah-langkah dalam analisis Pareto adalah sebagai berikut:

1. Mengidentifikasi permasalahan yang akan diteliti dan penyebab-penyebab kejadian.

2. Menentukan periode waktu yang diperlukan untuk analisis.

3. Membuat catatan frekuensi kejadian.

4. Membuat daftar masalah sesuai dengan urutan frekuensi kejadian.

5. Menghitung frekuensi kumulatif dan persentase kumulatif.

6. Gambarkan frekuensi dalam bentuk grafik batang.

7. Gambarkan persentase kumulatif dalam bentuk grafik garis.

8. Interpretasikan Pareto chart tersebut.

9. Mengambil tindakan berdasarkan prioritas kejadian/permasalahan.

10. Bila perlu ulangi langkah-langkah diatas untuk implementasi tindakan improvement guna melakukan perbandingan hasil. 


\section{HASIL DAN PEMBAHASAN}

\subsection{Analisa Keterlambatan yang} Disebabkan oleh Penanganan Teknik

Berdasarkan data yang diperoleh dari PT. GMF Aeroasia Tbk, berikut terdapat tingkat keterlambatan dan frekuensi terjadinya keterlambatan yang disebabkan oleh kegiatan maintenance atau technical delay oleh dinas Line Maintenance yang terjadi dalam kurun waktu satu tahun dimulai dari tanggal 1 Januari 2018 hingga 31 Desember 2018 pada pesawat jenis Boeing 777-300ER milik Garuda Indonesia Airlines. Data delay berdasarkan penyebab utama dikelompokkan berdasarkan standar IATA (International Air Transport Association) dengan delay code. Pada technical delay, delay code yang digunakan dimulai dari code 41 sampai dengan 48 .

Tabel 3.1 Data technical delay 2018

\begin{tabular}{|l|c|c|c|c|c|c|c|c|}
\hline \multirow{2}{*}{ BULAN } & \multicolumn{7}{|c|}{ DELAY CODE } \\
\hline & $\mathbf{4 1}$ & $\mathbf{4 2}$ & $\mathbf{4 3}$ & $\mathbf{4 4}$ & $\mathbf{4 5}$ & $\mathbf{4 6}$ & $\mathbf{4 7}$ & $\mathbf{4 8}$ \\
\hline JAN & 2 & & 1 & & & & & \\
\hline FEB & 2 & & 1 & & & & & \\
\hline MAR & & & 1 & & & & & \\
\hline APR & 2 & & 2 & & & 1 & & \\
\hline MAY & 1 & & 1 & & & 2 & & \\
\hline JUN & 1 & & & & & & & \\
\hline JUL & & & & & & 1 & & \\
\hline AUG & 2 & & & & & & & \\
\hline SEP & & & & & & 1 & & \\
\hline OCT & 1 & & 2 & & & & & \\
\hline NOV & 3 & & & & & 2 & & \\
\hline DEC & 5 & & 1 & & & 1 & & \\
\hline
\end{tabular}

Jika data tersebut dinyatakan dalam bentuk grafik maka diperoleh hasil seperti pada gambar 3.1.

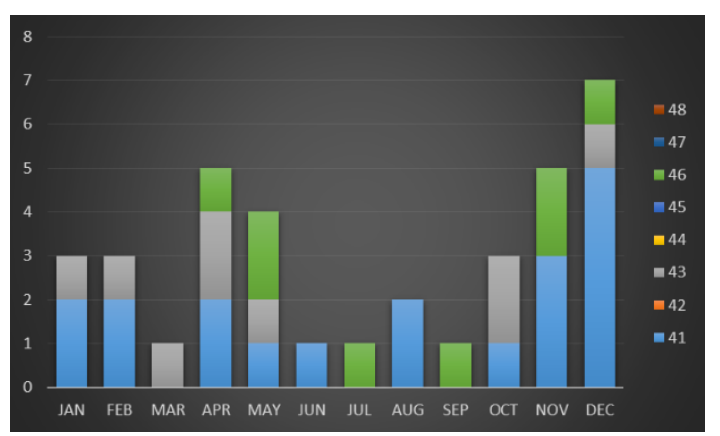

Gambar 3.1 Data Technical Delay 2018

\subsection{Analisa Dispatch Reliability}

Dispatch Reliability adalah parameter kunci untuk mencerminkan keandalan keseluruhan pesawat udara, dan juga parameter teknis penting perlu dipertimbangkan dalam desain asli pesawat sipil. Dispatch Reliability bisa didapatkan dari data flight cycle dari tiap pesawat dengan perhitungan:

DR $=100 \% \times($ Flight cycle - Jumlah Technical delay $) /$ Flight cycle

Untuk memenuhi perhitungan analisa tersebut maka dikumpulkan data flight cycle pesawat Boeing 777-300ER dalam satu tahun selama 2018 sebagai berikut:

Tabel 3.2 Data Utilisasi Pesawat

\begin{tabular}{|c|c|c|c|c|c|c|c|c|c|c|c|c|}
\hline A/C & JAN & FEB & MAR & APR & MAY & JUN & JUL & AUG & SEP & OCT & NOV & DES \\
\hline PK-GIA & 39 & 28 & 31 & 40 & 49 & 33 & 34 & 32 & 29 & 33 & 21 & 40 \\
\hline PK-GIC & 49 & 42 & 47 & 47 & 50 & 42 & 48 & 26 & 29 & 32 & 22 & 56 \\
\hline PK-GID & 37 & 40 & 49 & 29 & 30 & 37 & 41 & 40 & 53 & 39 & 31 & 40 \\
\hline PK-GIE & 44 & 36 & 38 & 42 & 36 & 39 & 23 & 24 & 58 & 49 & 46 & 39 \\
\hline PK-GIF & 62 & 55 & 54 & 55 & 48 & 54 & 56 & 58 & 55 & 61 & 65 & 67 \\
\hline PK-GIG & 52 & 61 & 58 & 56 & 51 & 53 & 56 & 58 & 56 & 53 & 64 & 61 \\
\hline PK-GIH & 48 & 49 & 54 & 39 & 52 & 37 & 32 & 30 & 50 & 53 & 44 & 50 \\
\hline PK-GII & 43 & 40 & 50 & 51 & 43 & 44 & 42 & 41 & 34 & 33 & 57 & 39 \\
\hline PK-GIJ & 40 & 43 & 39 & 53 & 49 & 33 & 42 & 24 & 33 & 28 & 54 & 50 \\
\hline PK-GIK & 39 & 39 & 41 & 46 & 42 & 38 & 36 & 27 & 30 & 51 & 48 & 44 \\
\hline Total & 453 & $\mathbf{4 3 3}$ & $\mathbf{4 6 1}$ & $\mathbf{4 5 8}$ & $\mathbf{4 5 0}$ & $\mathbf{4 1 0}$ & $\mathbf{4 1 0}$ & $\mathbf{3 6 0}$ & $\mathbf{4 2 7}$ & $\mathbf{4 3 2}$ & $\mathbf{4 5 2}$ & $\mathbf{4 8 6}$ \\
\hline
\end{tabular}


Dispatch Reliability Januari 2018

$\mathrm{DR}=100 \% \times(453-3) / 453$

$\mathrm{DR}=99,34 \%$

Dispatch reliability setiap bulan selama tahun 2018 hasil perhitungan seperti pada gambar

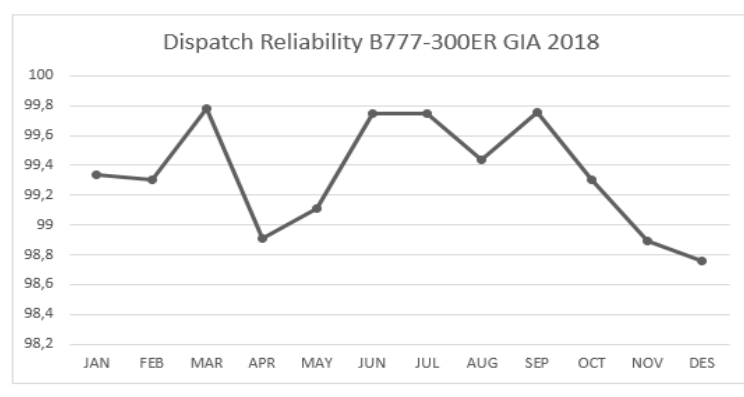

Gambar 3.2 Dispatch Reliability 2018

Dispatch Reliability tertinggi sebesar DR = 99,78\% pada bulan Maret 2018 dengan jumlah flight cycle 461 hanya terjadi satu kali technical delay.

Nilai Dispatch Reliability terendah terdapat pada bulan Desember dengan nilai $\mathrm{DR}=98,76 \%$ dari jumlah flight cycle sebanyak 486 terjadi enam kali technical delay.

\subsection{Analisa Metode Pareto Keterlambatan yang Disebabkan oleh Penanganan Teknik}

Berdasarkan data keterlambatan penerbangan yang disebabkan oleh penanganan teknik pada pesawat Boeing 777-300ER milik Garuda Indonesia Airlines dalam periode satu tahun (1 Januari 2018 hingga 31 Desember 2018) di unit Line Maintenance, PT. GMF Aeroasia Tbk, didapatkan beberapa kejadian yang terulang pada beberapa delay code yang digambarkan dalam diagram batang berikut:

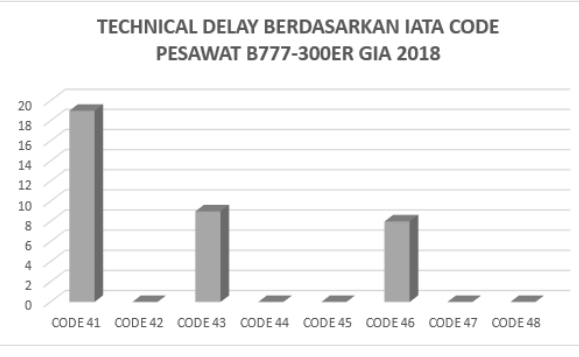

Gambar 3.3 Technical delay berdasarkan IATA delay code

Dengan data kejadian yang berulang tersebut dapat dilakukan analisa dengan metode Pareto yang menunjukkan masalah berdasarkan urutan banyaknya jumlah kejadian. Urutannya mulai dari jumlah permasalahan yang paling banyak terjadi sampai yang paling sedikit terjadi.

Tabel 3.3 Analisis Pareto delay code

\begin{tabular}{|c|c|c|c|}
\hline $\begin{array}{c}\text { IATA DELAY } \\
\text { CODE }\end{array}$ & FREKUENSI & $\begin{array}{c}\text { PERSEN } \\
(\%)\end{array}$ & $\begin{array}{c}\text { AKUMULASI } \\
(\%)\end{array}$ \\
\hline CODE 41 & 19 & 52,78 & 52,78 \\
\hline CODE 42 & 0 & 0 & 52,78 \\
\hline CODE 43 & 9 & 25 & 77,78 \\
\hline CODE 44 & 0 & 0 & 77,78 \\
\hline CODE 45 & 0 & 0 & 77,78 \\
\hline CODE 46 & 8 & 22,22 & 100 \\
\hline CODE 47 & 0 & 0 & 100 \\
\hline CODE 48 & 0 & 0 & 100 \\
\hline TOTAL & 36 & 100 & \\
\hline
\end{tabular}

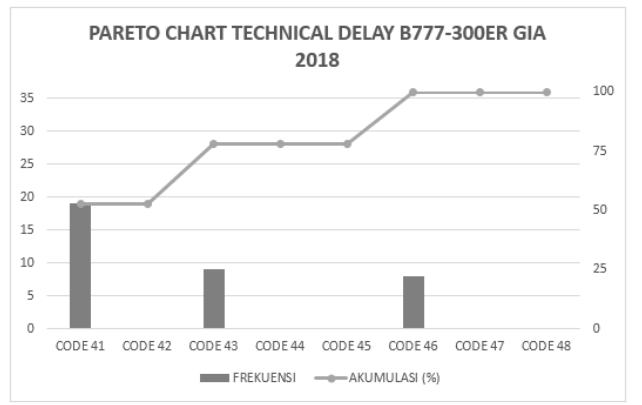

Gambar 3.4 Pareto Chart delay code

Dari hasi analisis diatas, digambarkan dalam diagram Pareto dengan kurang lebih $80 \%$ masalah yang terjadi diakibatkan hanya dari $20 \%$ golongan 
keterlambatan penerbangan yang disebabkan oleh penanganan teknik berdasarkan delay code.

Dari diagram diatas dapat dilihat bahwa persentase delay code 41 sebesar $52,78 \%$ yang mana kejadian keterlambatan akibat penanganan teknik disebabkan oleh aircraft defects. Delay code 43 sebesar $25 \%$ terjadi disebabkan oleh perawatan tidak terjadwal, pemeriksaan khusus dan atau pekerjaan tambahan di luar perawatan normal. Kemudian delay code 46 sebesar $22,22 \%$ terjadi dikarenakan pergantian pesawat dengan alasan teknis.

Berdasarkan data yang terkumpul, technical delay yang terjadi dengan delay code 41 , delay code 43 , dan delay code 46 dapat digolongkan lagi berdasarkan ATA chapter yang sering terjadi atau memiliki frekuensi terbanyak sebagai berikut:

$\begin{array}{lll}\text { ATA } 12: 1 \text { kali } & \text { ATA } 29: 1 \text { kali } & \text { ATA } 38: 2 \text { kali } \\ \text { ATA } 21: 1 \text { kali } & \text { ATA } 30: 1 \text { kali } & \text { ATA } 49: 1 \text { kali } \\ \text { ATA } 24: 2 \text { kali } & \text { ATA } 31: 2 \text { kali } & \text { ATA } 52: 4 \text { kali } \\ \text { ATA } 26: 3 \text { kali } & \text { ATA } 32: 2 \text { kali } & \text { ATA } 73: 2 \text { kali } \\ \text { ATA } 27: 4 \text { kali } & \text { ATA } 34: 2 \text { kali } & \text { ATA } 78: 2 \text { kali } \\ \text { ATA } 28: 5 \text { kali } & \text { ATA } 36: 1 \text { kali } & \text { ATA } 80: 1 \text { kali }\end{array}$

Dari catatan frekuensi kejadian technical delay yang digolongkan berdasarkan ATA Chapter tersebut dilakukan analisis menggunakan metode Pareto, kemudian menghitung frekuensi kumulatif dan persentase kumulatif maka didapatkan hasil dalam diagram sebagai berikut:

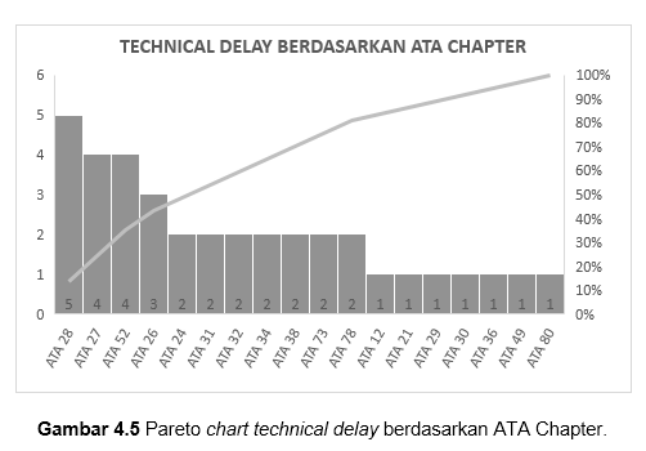

Pada diagram diatas terlihat ada tiga golongan ATA Chapter dengan frekuensi terbanyak yaitu ATA chapter 28 (Fuel System) sebanyak lima kali kejadian, ATA chapter 27 (Flight Control system) sebanyak empat kali kejadian, dan ATA chapter 52 (Door) sebanyak 4 kali kejadian. Dengan demikian maka perlu diperhatikan permasalahanpermasalahan yang sering terjadi pada technical delay yang disebabkan oleh ketiga ATA Chapter tersebut serta akibat sistem dari pesawat itu sendiri secara berulang dalam kegiatan maintenance baik yang sudah terjadwal maupun yang tidak terjadwal sehingga meminimalkan terjadinya technical delay.

\subsection{Solusi dari Hasil Analisa Pareto}

Dari hasil analisa dengan metode Pareto diatas dapat disimpulkan bahwa terjadinya keterlambatan penerbangan yang disebabkan oleh penanganan teknik paling sering terjadi diakibatkan oleh aircraft defect, perbaikan dan atau perawatan pesawat diluar schedule atau tambahan, dan pergantian pesawat dengan alasan teknis seperti tidak tersedianya material atau komponen yang 
dibutuhkan. Untuk mencegah atau mengantisipasi hal-hal yang demikian, maka beberapa solusi yang dapat dilakukan adalah sebagai berikut:

1. Dalam perbaikan dan perawatan pesawat dilakukan sesuai prosedur, terjadwal, dan tidak mentoleransi hal-hal yang mengurangi atau mengganggu airworthiness dari pesawat.

2. Ketersediaan material harus memenuhi minimum dan maksimum requirement yang mana didapatkan dari hasil analisa kebutuhan material dalam setiap program maintenance guna mencegah tidak tersedianya material yang dapat mengganggu operasional pesawat apabila dibutuhkan pergantian material atau komponen untuk pesawat online sehingga tidak diperlukan mengganti pesawat.

3. Mempertimbangkan ketersediaan armada, schedule maintenance, track record dalam ketepatan waktu dan mengetahui faktor - faktor lain yang banyak menyebabkan delay sehingga bisa dihindari.

4. Mengembangkan personel (teknisi atau engineer) untuk release pesawat atau stamp administrasi dokumen maintenance diperlukan development dengan trainingtraining yang terkait agar tidak kekurangan personel dalam menyelesaikan load maintenance yang banyak dalam waktu yang sudah ditentukan.

\section{KESIMPULAN}

1. Terjadi 19 kali keterlambatan yang disebabkan oleh penanganan teknik dengan delay code 41, 9 kali delay code 43, dan 8 kali delay code 46 .

2. Persentase delay code 41 sebesar $52,78 \%$ disebabkan oleh aircraft defects. Delay code 43 sebesar $25 \%$ disebabkan oleh perawatan tidak terjadwal, pemeriksaan khusus dan atau pekerjaan tambahan di luar perawatan normal. Delay code 46 sebesar 22,22\% terjadi dikarenakan pergantian pesawat dengan alasan teknis.

3. Dari hasil analisa Pareto berdasarkan ATA Chapter terdapat tiga ATA dengan frekuensi terbanyak yaitu ATA chapter 28 sebanyak lima kali kejadian, ATA chapter 27 sebanyak empat kali kejadian, dan ATA chapter 52 sebanyak 4 kali kejadian.

\section{DAFTAR PUSTAKA}

[1] Crocker, David : Dictionary of Aviation Second Edition, A\&C Black Publishers, London, 2007.

[2] Gunawan, Herry : Pengantar Transportasi dan Logistik, PT. Rajagrafindo Persada, Jakarta, 2014.

[3] Handoko, Singgih dan Dudi Sudibyo : AVIAPEDIA - Ensiklopedia Umum 
Penerbangan, PT. Kompas Media Nusantara, Jakarta, 2014.

[4] Majid, Suharto Abdul dan Eko Probo

D. Warpani : Ground Handling Manajemen Pelayanan Darat Perusahaan Penerbangan, PT. Rajagrafindo Persada, Jakarta, 2014.

[5] Majid, Suharto Abdul : Customer Service Dalam Bisnis Jasa Transportasi, PT. Raja Grafiondo Persada, Jakarta, 2019.

[6] IATA Delay code edisi revisi Juni 2017.

[7] UU Penerbangan No. 1 Tahun 2009. Tentang Pengertian Angkutan Udara Pasal 1 nomor 48 Undang-Undang No. 1 tahun 2009 tentang Pengertian Keselamatan Penerbangan.

[8] Handoko, T. Hani : Dasar-dasar Manajemen Produksi dan Operasi, BFPE, Yogyakarta, 2012.

[9] Sugiyono : Metode Penelitian Administrasi, Alfabeta, Jakarta, 2012.

[10] Trijono, Rachmat: Metode Penelitian Kuantitatif, Papas Sinar Sunanti, Jakarta, 2015. 